\title{
STUDIES ON HYGIENIC STATUS OF KISHK PRODUCT
}

\author{
M-T. A. EL-SHREEF LAMIAA and M. N. EL-GENDI MARWA \\ Animal Health Research Institute, Assiut Regional Laboratory. \\ Email: moazahmednofel@yahoo.com
}

\section{ABSTRACT}

Received at: 30/12/2014

Accepted: 10/2/2014
This study was carried out for monitoring the bacteriological and mycological quality of Kishk. Thirty six random samples of Kishk were collected from different farmer producer and shops in Assiut city and some villages around it. All samples were subjected to microbiological examinations and mycotoxine investigation. Enterococci spp., Aerobic bacteria, Anaerobic bacteria and "Yeasts and molds" were isolated in 61.6, 100, 86.1 and $77.8 \%$ of the examined Kishk samples, respectively, and with average total counts of 6.95 $\times 10^{4}, 2.26 \times 10^{5},--$, and $3.9 \times 10^{4}$, respectively. The presence of high contamination in Kishk samples reflects the poor sanitary conditions during the manufacturing stages or post production. Aspergillus flavus, Aspergillus niger and Mucor spp. were detected in 22.2, 16.7 and $8.3 \%$ of the examined Kishk samples, respectively. Aflatoxin $\mathrm{M}_{1}$ was found in $23.53 \%$ of the samples. The concentration of aflatoxin $\mathrm{M}_{1}$ in positive samples was $139-221 \mathrm{ng} / \mathrm{Kg}$ (average $149.8 \pm 56.5 \mathrm{ng} / \mathrm{Kg}$ ) by ELISA and $56-218 \mathrm{ng} / \mathrm{Kg}$ (average $135.3 \pm 61.5$ $\mathrm{ng} / \mathrm{Kg}$ ) by TLC. Kishk samples from Assiut city presented a high incidence of $\mathrm{AFM}_{1}$ at levels below the limits established by Egyptian regulations. The general human exposure to $\mathrm{AFM}_{1}$ by the consumption of contaminated kishk is probably non-significant in Egypt. However, the fact that $\mathrm{AFM}_{1}$ is a potent hepatocarcinogen warrants concern about its occurrence in kishk. A high percentage of positive samples would be considered inappropriate for human consumption, when considering the tolerance limit adopted by the European Community. It could be concluded that, the product quality is variable, with some samples showing noticeably more contamination than others. This is probably a reflection of the standards of hygienic measures applied during production and the quality of raw materials used (fermented milk and crushed dried boiled wheat grains).

Key words: Kishk, Fermented milk, Crushed wheat grains.

\section{INTRODUCTION}

Kishk is one of the natural healthy food products, which have great taste and cultural values that are increasingly attractive to the Egyptian consumers. The traditional method for the manufacture of Kishk is very basic (composed mainly of crushed dried boiled wheat grains and acidified milk). The microbiological quality of the product is mainly governed by factors such as: 1 - the method used to ferment the milk; 2- the hygienic conditions practiced during the manufacturing stages including whether the milk was heat treated (boiled) or not before the fermentation stage; and 3- the drying stage in the open air in sunny areas (Tamime and O'Conner, 1995).

Three possible types of milk fermentation may be distinguished during the manufacture of Kishk: first, is the use of starter culture where the indigenous microflora is used to ferment the unheated milk; second, 'artisan' starter culture is normally used frequently by seeding the milk with yoghurt or another type of fermented milk from the previous day's batch, and hence, the starter composition may be variable; and third, selected lactic starter cultures obtained from commercial sources of known composition. It is evident that acidification of milk can prolong the shelf-life of the manufactured products. Likewise, limited data are available on the microbiological quality of Kishk. Nevertheless, the low moisture content $(10 \%)$, acidic nature of the product $(\mathrm{pH} 3.8)$ and the addition of salt during manufacture (2.8 g NaCI / $100 \mathrm{~g}$ dried product) may be the cause of microbiological safety of Kishk (Tamime et al., 1999).

It's reported that, Lactobacilli isolated from dairy products have shown a long history of safe use (WHO/FAO, 2001). They are used widely as starter 
cultures in the food industry, e.g. fermented milk or meat products, alcoholic beverages, sourdough and silage (Carr et al., 2002). Furthermore, cultures of various Lactobacillus strains have been developed for commercial use as probiotic bacteria.

The genus Lactobacillus has a long history of safe use, especially in the dairy industry, and plays a major role in the production of fermented milk products. Over the past few decades, an increased drive has existed for the isolation of novel Lactobacillus strains which termed probiotic exert a beneficial health effect when ingested by humans. Accordingly beneficial effects conferred by lactobacilli include inhibition of pathogenic organisms, such as Salmonella, Shigella and Helicobacter (Bernet-Camard et al., 1997; Hudault et al., 1997; Aiba et al., 1998; Hammilton- Miller, 2003 and Sgouras et al., 2004).

During the past two decades, probiotic (health promoting) microorganisms have been increasingly included in various types of food products, especially in fermented milks. Actually, a large population of probiotic bacteria is needed to carry out their benefit effect and to repel the harmful microorganisms causing disease. Indeed, some probiotic strains are rapidly killed by acid and bile, releasing active intracellular components as bacterial formylated peptides, peptidoglycan cell wall constituents and nucleotides (Ouwehand and Salminen, 1998; Salminen et al., 1999 and De Vrese et al., 2001). The technological application of probiotic organisms in fermented dairy products aims to combine the potential health benefits of the bacteria with their ability to grow in milk, resulting in a nutritionally healthy and desirable product for the consumers. Also, Gomez et al. (1997) evidenced a bacteriocinlike substance produced by a new strain of Streptococcus spp., inhibitory to Gram positive foodborne pathogens.

During the last fifteen years, the Lactobacillus genus has evolved and contains to date more than 80 species. They are present in raw milk and dairy products such as cheeses, yoghurts and fermented milks (Coeuret et al., 2003). Lactobacilli comprise large and diverse group of Gram positive, non-spore forming, catalase negative rod bacteria, able to produce lactic acid as the main end-product of the fermentation of carbohydrates (Pelinescu et al., 2009). They are considered as generally recognized as safe organisms and can be safely used as probiotics for medical and veterinary applications (Fuller, 1989).

Fermented milk present in Kishk product may be contaminated with enterococci, coliforms and Escherichia coli. Mundt (1986) demonstrated that the common presence of E. faecalis in many food products is not always related to direct faecal contamination. In 1992, the EU established a maximum level for the presence of coliforms and Escherichia coli, both considered as indicators of hygiene, while no limit was set for the enterococci (Anonymous, 1992). Furthermore, it has been shown that enterococci had little value as hygiene indicators in the industrial processing of foods (Bernet-Camard, et al., 2001). Moreover, although E. faecalis, E. faecium, and E. durans are frequently isolated from human faeces, they are much less prevalent in livestock, such as pigs, cattle, and sheep (Franz et al., 1999).

Fermented milk present in Kishk product may also contains aflatoxin $\mathrm{M}_{1}$ (hepatocarcinogen) especially if the used milk obtained from animals fed on mycotoxine (aflatoxin $\mathrm{B}_{1}$ ) contaminated ration (Park and Pohland, 1986). Aflatoxin $\mathrm{M}_{1}\left(\mathrm{AFM}_{1}\right)$ is the main metabolite produced by storage fungi of the genus Aspergillus, particularly Aspergillus flavus, Aspergillus parasiticus and Aspergillus nomius (Moss, 1998). The occurrence of $\mathrm{AFM}_{1}$ in milk and milk products is of public health concern. The International Agency for Research on Cancer (1993) has classified $\mathrm{AFM}_{1}$ in group 2, a probable human carcinogen.

Many traditional foods are threatened as lifestyles are changed and local know-how is lost. Systematic investigation and registration of traditional foods can help to keep them on the menu, thus enabling future generation to experience and enjoy traditional local specialties. This work aimed to investigate the probiotic bacteria present in Kishk product and to evaluate its hygienic quality through the isolation and identification of some microorganisms that may contaminate it. Also, to detect the possible occurrence of aflatoxine $\mathrm{M}_{1}$ in various locally manufactured Kishk.

\section{MATERIALS and METHODS}

\section{1) Samples: collection, preparation and serial dilutions:}

Thirty six random samples of Kishk collected in clean, dry and sterile containers from framer producing kishk at several villages and some shops in Assiut city. Samples transported directly to laboratory for investigations. Each sample was divided under complete hygienic measures with a clean, sterile knife into two parts; the first was prepared for microbiological examination. The preparation of each sample and dilutions was carried out according to the method described by A.P.H.A. (1992) and IDF (1992). $10 \mathrm{~g}$ of each Kishk sample was homogenized in $90 \mathrm{ml}$ of sterile $2 \%$ sodium citrate solution at $7^{\circ} \mathrm{C}$ for $15 \mathrm{~s}$. Serial dilutions were made in $1 / 4$ strength sterile Ringer's solution and plated in duplicate on specific agar, and the average of the determinations 
was expressed as cfu/g. The other part was used for mycotoxins estimation.

2) Enumeration, isolation and identification of Lactoabacilli bacteria was carried out according to De Man et al. (1960) with the using of MRS agar and incubation at anaerobic conditions at $37^{\circ} \mathrm{C}$ for $48 \mathrm{hrs}$.

3) Enumeration, isolation and identification of Enterococci was carried out according to Deibel and Hartman (1982) using KF streptococcal agar and Azide dextrose broth.

4) Estimation of total bacterial count was carried out according to A.P.H.A. (1992) by using standard plate count agar.

5) Estimation of total yeasts and molds count was carried out according to Harrigan and MacCance (1976) by using malt extract agar contained $500 \mathrm{mg}$ of chlortetracycline and chloramphenicol.

6) Detection of anaerobic bacteria using Stormy fermentation test according to Crückshank et al. (1969).

7) Detection of Aflatoxin $\mathbf{M}_{\mathbf{1}}$ : Thirty four samples were randomly chosen for the estimation of the aflatoxin $\mathrm{M}_{1}$. Fifty grams of each chosen sample were mashed, homogenized with organic solvents and extracted for estimation of the mycotoxins. The toxins were extracted from the kishk samples with a mixture of acetonitrile: phosphoric acid, $0.1 \mathrm{M}$ (10:1, $\mathrm{V} / \mathrm{V}$ ) and the extract was purified by liquid-liquid partition with isooctane to remove lipid material and with a mixture of aqueous sodium hydrogen carbonate and sodium chloride to separate acids from the neutral substances. Detection of Aflatoxin $\mathrm{M}_{1}$ $\left(\mathrm{AM}_{1}\right)$ by using ELISA was carried out according to Thirumalla-Devi et al. (2002) and by using thin layer chromatography according to Egmond and Paulsch (1986) and Schuller and Egmond (1991) (Multimycotoxin analysis).

\section{RESULTS}

Physical examination of each Kishk sample was carried out by naked eye and revealed absence of any abnormal findings. Isolated microorganisms ( $\%$ of positive samples and total count $/ \mathrm{g}$ ) and percentage of isolated fungi in the examined Kishk samples are shown in Tables 1 and 2 respectively. Aflatoxin $\mathrm{M}_{1}$ (ng / Kg) in examined Kishk samples are shown in Table 3.

Table 1: Isolated microorganisms in the examined Kishk samples.

\begin{tabular}{cccccc}
\hline & \multicolumn{5}{c}{ Examined samples } \\
( No.: 36) \\
\cline { 2 - 6 } Isolated microorganisms & Positive samples & \multicolumn{3}{c}{ Total counts / g } \\
\cline { 2 - 6 } & No. & $\%$ & Min. & Max. & Average \\
\cline { 2 - 6 } & 0 & 0 & 0 & 0 & 0 \\
\hline Lactobacillus spp. & 22 & 61.1 & $<100$ & $1.58 \times 10^{6}$ & $6.95 \times 10^{4}$ \\
\hline Enterococci spp. & 36 & 100 & $5 \times 10^{3}$ & $2.20 \times 10^{6}$ & $2.26 \times 10^{5}$ \\
\hline Aerobic plate count & 31 & 86.1 & - & - & - \\
\hline Detected anaerobic bacteria & 28 & 77.8 & $<100$ & $5.8 \times 10^{5}$ & $3.9 \times 10^{4}$ \\
\hline Yeasts and fungi & & & & &
\end{tabular}

Table 2: Types and percentage of isolated fungi in the examined Kishk samples.

\begin{tabular}{ccc}
\hline \multirow{2}{*}{ Fungal species } & \multicolumn{2}{c}{ Examined samples } \\
& \multicolumn{3}{c}{ ( No.: 36) } \\
\cline { 2 - 3 } & Positive samples & $\%$ \\
\hline Aspergillus flavus & 8 & 22.2 \\
\hline Aspergillus niger & 6 & 16.7 \\
\hline Mucor spp. & 3 & 8.3 \\
\hline
\end{tabular}


Assiut Vet. Med. J. Vol. 60 No. 140 January 2014

Table 3: Aflatoxin $M_{1}(\mathrm{ng} / \mathrm{Kg})$ in the examined Kishk samples.

\begin{tabular}{|c|c|c|c|c|}
\hline \multirow{2}{*}{$\begin{array}{c}\text { Number of } \\
\text { examined samples }\end{array}$} & \multirow{2}{*}{$\begin{array}{c}\text { Estimation } \\
\text { method }\end{array}$} & \multicolumn{2}{|c|}{ Positive samples } & \multirow{2}{*}{$\begin{array}{c}\text { Concentration of Aflatoxin } M_{1} \\
(\mathbf{n g} / \mathbf{K g}) \\
\text { Mean } \pm \text { SD }\end{array}$} \\
\hline & & Number & $\%$ & \\
\hline 34 & TLC & 8 & 23.53 & $135.3 \pm 61.5$ \\
\hline 34 & ELISA & 8 & 23.53 & $149.8 \pm 56.5$ \\
\hline
\end{tabular}

ELISA: Enzyme linked immunosorbent assay.

\section{DISCUSSION}

Kishk made of acidified milk and crushed dried boiled wheat grains. It is rich in nutritive constituents and source for many vitamins, growth factors and other nutrients. Although, Kishk product has low moisture content (10\%), acidic nature $(\mathrm{pH} \mathrm{3.8)}$ and high percentage of salt $(2.8 \mathrm{~g} \mathrm{NaCI} / 100 \mathrm{~g}$ dried product) which may suggest its microbiological safety (Tamime et al., 1999), it may be subjected to contamination with several organisms. In the present study Enterococci spp., Aerobic bacteria, Anaerobic bacteria and "Yeasts and Fungi" were isolated in $61.6,100,86.1$ and $77.8 \%$ of the examined Kishk samples, respectively, and with average total count of $6.95 \times 10^{4}, 2.26 \times 10^{5}$, - , and $3.9 \times 10^{4}$, respectively (Table 1). The presence of high contamination in Kishk samples reflects the poor sanitary conditions during the manufacturing stages or post production. Faecal Enterococci count at a level of $3.4 \times 10^{2}$ colony forming units (cfu/g) was reported by Atia and Khattab (1985) in only one of eight tested Egyptian Kishk samples. However, groups of undesirable microorganisms mainly spore-formers (i.e. Bacillus spp.), yeasts and molds, were found in different commercial samples of Kishk (Tamime and O'Connor, 1995). In Iran, the death of two people, who had clinical symptoms of botulism food poisoning, was found to be associated with the consumption of Kishk, the auther reported the growth, survivaI and production of toxin of Clostridium botulinum in laboratory-made Kishk (Haydarynia, 1990).

In recent years, the reports about Enterococci used as starter cultures or co-cultures (adjuncts) have increased considerably. Enterococci occur in soil, surface waters, and on plants, vegetables, and insects (Mundt, 1986). The resistance of Enterococci to pasteurization temperatures, and their adaptability to different substrates and growth conditions (low and high temperature, extreme $\mathrm{pH}$, and salinity) implies that they can be found either in food products manufactured from raw materials (milk or meat) and in heat-treated food products. This means that these bacteria could withstand usual conditions of food production. In addition, they can contaminate finished products during food processing. Therefore, enterococci can become an important part of the fermented food microbiota, especially in fermented cheeses and meats. Moreover, although E. faecalis, E. faecium, and E. durans are frequently isolated from human faeces, they are much less prevalent in livestock, such as pigs, cattle, and sheep (Franz et al., 1999).

Aspergillus flavus, Aspergillus niger and Mucor spp. were detected in 22.2, 16.7 and $8.3 \%$ of the examined Kishk samples, respectively. Slightly lower yeasts and molds counts have been recorded in Kishk (Tamime and O'Connor, 1995). In previous study, high yeast count was fond in kishk samples and the author attributed this to the use of "artisan" starter culture which may contain lactose fermenting yeast (Baroudi and Collins, 1976).

Aflatoxin $\mathrm{M}_{1}$ was found in $23.53 \%$ of the examined Kishk samples. The concentration of aflatoxin $\mathrm{M}_{1}$ in positive samples was 139 - $221 \mathrm{ng} / \mathrm{Kg}$ (average 149.8 $\pm 56.5 \mathrm{ng} / \mathrm{Kg}$ ) by ELISA and $56-218 \mathrm{ng} / \mathrm{Kg}$ (average $135.3 \pm 61.5 \mathrm{ng} / \mathrm{Kg}$ ) by TLC. These findings revealed that the concentration of $\mathrm{AFM}_{1}$ was relatively higher when estimated by ELISA than when estimated by TLC. Statistically there were insignificant variations between results obtained by the two methods used in the detection of aflatoxin $\mathrm{M}_{1}$ in Kishk samples. These results indicated that the $\mathrm{AFM}_{1}$, present in high levels in some samples and constitute a potential hazard for the consumers. It has been emphasized that consumption of aflatoxin $M_{1}$ probably constitute a much more serious public health problem. In many cases potential problems involve the possibility of carcinogens in human. Affected human may also predisposed to secondary infectious diseases because of the immune suppressive effect of the aflatoxins (Howard, 1983; Shan, 1991 and Oliveira and Germano, 1997).

The European Communities and Codex Alimentarius have fixed the limit to a maximum of $50 \mathrm{ng} \mathrm{AFM}_{1} /$ 
$\mathrm{kg}$ (Anonymous, 2001). In the Turkish Food Codex (Anonymous, 1997), $\mathrm{AFM}_{1}$ levels in milk were limited to $50 \mathrm{ng} / \mathrm{kg}$, similar to that of EC/Codex Regulations. Due to toxicity, most countries have set up maximum permissible levels of $\mathrm{AFM}_{1}$ in milk, which varies from $50 \mathrm{ng} / \mathrm{kg}$ established by the EU to the $500 \mathrm{ng} / \mathrm{kg}$ established by US FDA (European Commission, 2003 and F.D.A., 2011). More restrictive MRLs have been decided by the EU for the presence of $\mathrm{AFM}_{1}$ in baby food (European Commission, 2004).

Aflatoxin contamination in milk and its products is produced in two ways, either passage of toxins to milk with ingestion of feeds contaminated with aflatoxin, or it results as subsequent contamination of milk and milk products with fungi (Sarimehmetoglu et al., 2003). Aflatoxin $\mathrm{M}_{1}$ occurrence in milk and dairy products is an important issue because many people consume these products on a daily basis, especially for the growing infant population which depend on milk as a major nutrient.

\section{CONCLUSION}

It could be concluded that, the product quality is variable, with some samples showing noticeably more contamination than others. This is probably a reflection of the standards of hygienic measures applied during production and the quality of raw materials used (fermented milk and crushed dried boiled wheat grains), it indicates that with improved hygiene, the microbiological quality of the Kishk could be improved. Kishk samples from Assiut city presented a high incidence of $\mathrm{AFM}_{1}$ at levels below the limits established by Egyptian regulations. A high percentage of positive samples would be considered inappropriate for human consumption, when considering the tolerance limit adopted by the European Community. The general human exposure to $\mathrm{AFM}_{1}$ by the consumption of contaminated Kishk is probably non-significant in Egypt. However, the fact that $\mathrm{AFM}_{1}$ is a potent hepatocarcinogen warrants concern about its occurrence in Kishk, especially those intended for child populations. For this reason, milk and milk products have to be controlled continuously for presence of $\mathrm{AFM}_{1}$ contamination. It is also extremely important to maintain low levels of AFB in the feeds of dairy animals. In order to achieve this, dairy cow feeds should be kept away from contamination as much as possible and should be checked regularly for aflatoxin and, particularly important, storage conditions of feeds must be strictly controlled.

\section{REFERENCES}

A.P.H.A. (1992): Standard Methods for the Examination of Dairy Products. $13^{\text {th }} \mathrm{ed}$., American Public Health Association.
Aiba, Y.; Suzuki, N.; Jabir, A.M.; Tamaki, A. and Koga, Y. (1998): Lactic acid mediated suppression of Helicobacter pylori by the oral administration of Lactobacillus salivarious as a probiotic in a genotobiotic murine model. American J. of Gastroenterology, 93: 20972101.

Anonymous (1992): EEC council directive of 16 June 1992 on milk hygiene (92/46EEC). Official Journal of the European Community L268/1, 14.9.1992.

Anonymous (1997): Türk. G1da Kodeksi Yönetmeliği. Resmi Gazete, 16 Kasim 1997. Sayı: 23172, Başbakanlık Basımevi, Ankara.

Anonymous (2001): Comments submitted on the draft maximum level of aflatoxin $\mathrm{M}_{1}$ in milk. Codex Committee on Food Additives and Contaminants $33^{\text {rd }}$ session, Hague, Netherlands.

Atia, I.A. and Khattab, A.A. (1985): Microbiological and chemical studies on Kishk. Alexandria Sci. Exchange 6: 63-71.

Baroudi, A.A. and Collins, E.B. (1976): Microorganisms and characteristics of Laban. 1. Dairy Sci. 59: 200-202.

Bernet-Camard, M.F.; Lievin, V.; Brassart, D.; Neeser, J.R.; Servin, A.L. and Hudault, S. (1997): The human Lactobacillus acidophilus strain LA1 secretes a nonbacteriocin antibacterial substance (s) active in vitro and in vivo. Appl. Environ. Microbiol., 63: 27472753.

Bernet-Camard, M.F.; Lievin, V.; Brassart, D.; Neeser, J.R.; Servin, A.L.; Birollo, G.A.; Reinheimer, J.A. and Vinderola, C.G. (2001): Enterococci vs. non lactic acid microflora as hygiene indicators for sweetened yoghurt. Food Microbiol. 18: 597-604.

Carr, F.J.; Chill, D. and Maida, N. (2002): The lactic acid bacteria, a literature survey. Crit. Rev. Microbiol., 28: 281-370.

Coeuret, V.; Dubernet, S.; Bernardeau, M.; Gueguen, $M$. and Vernoux, J.P. (2003): Isolation, characterization and identification of Lactobacilli focusing mainly on cheeses and other dairy products. Lait, 83: 269-306.

Crückshank, R.; Duguid, J.P. and Swain, R.H. (1969): Medical Microbiology $11^{\text {th }}$ ed. E. S. Livingston Limited Edinburgh, London.

Deibel, R.H. and Hartman, P.A. (1982): The Enterococci. In: Compendium of Methods for the Microbiological Examination of Foods. M.L., Speck (ed.), $2^{\text {nd }}$ ed., American Public Health Association.

De Man, J.C.; Rogosa, M. and Sharpe, M.T. (1960): A medium for cultivation of Lactobacilli. J. Appl. Bacteriol., 23: 130-135.

DeVrese, M.; Stegelmann, A.; Richter, B.; Fenselau, S.; Laue, C. and Schrezenmeir, J. (2001): 
Probiotics-compensation for lactase insufficiency. Am. J. Clin. Nutr., 73: 421-429.

Egmond, H.P. and Paulsch, W.E. (1986): Mycotoxins in milk and milk products. Netherlands Milk and Dairy J. 49 (2-3): 175.

European Commission (2003): Commission regulation (EC) No 100/2003. Official Journal of the European Community, L285: 33-37.

European Commission (2004): Commission regulation (EC) No 683/2004. Official Journal of the European Community, L106: 3-5.

Franz, C.M.; Holzapfel, W.H. and Stiles, M.E. (1999): Enterococci at the cross roads of food safety? Int. J. Food Microbiol., 47: 1-24.

Fuller, R. (1989): Probiotic in man and animals. A Review J. of Appl. Bacteriol., 90: 3452-3453.

Gomez, S.; Cosson, C. and Deschamps, A.M. (1997): Evidence for a bacteriocin-like substance produced by a new strain of Streptococcus sp., inhibitory to Gram-positive foodborne pathogens. Original Research Article Research in Microbiology, 148: 757-766.

Hammilton-Miller, J.M. (2003): The role of probiotics in the treatment and prevention of H. pylori infection. Int. J. of Antimicrobial Agents, 22: 360-366.

Harrigan, W.F. and MacCance, M.F. (1976): Laboratory Methods in Food and Dairy Microbiology (Revised Edition). 452 S., 24 Abb. London-New York, San Francisco, 1976.

Haydarynia, A. (1990): The survival of Clostridium botulisium in Kishk, $23^{\text {rd }}$ Int. Dairy Congress Brief Commun., 1, 1 OS.

Howard, D.H. (1983): Fungi Pathogenic for Human and Animal. Text Book (in three parts), Part B, Pathogenicity and detiction: 1, Volume 3, Marcel Dekker,Inc, New York and Basel.

Hudault, S. (1997): The human Lactobacillus acidophilus strain $\mathrm{LA}_{1}$ secretes a nonbacteriocin antibacterial substance (s) active in vitro and in vivo. Appl. Environ, Microbiol., 63: 2747-2753.

Hudault, S.; Lievin, V.; Bernet-Camard, M.F. and Servin, A.L. (1997): Antagonistic activity exerted in vitro and in vivo by Lactobacillus casei (Strain GG) against Salmonella typhimurium $C_{5}$ infection. Appl. and Environ. Microbiol., 63: 513-518.

IDF (1992): Milk and milk products, preparation of samples and dilutions for microbiological examination, Standard 122B, International Dairy Federation, Brussels, Belgium, 1992.

International Agency for Research on Cancer (1993): Some naturally occur substances: Food items and constituents, heterocyclic aromatic amines and mycotoxins. Monographs on the evaluation of carcinogenic risks to humans, Lyon: IARC 56: 489-521.
Moss, M.O. (1998): Recent studies of mycotoxins. J. Appl. Microbiol., 84: 62S-76S, Symposium Supplement.

Mundt, O.J. (1986): Enterococci. In: Sneath, P. H.; Mair, N. S.; Sharpe, M. E.; Holt, J. G. (Eds.), Bergey's Manual of Systematic Bacteriology, vol. 2. Williams and Wilkins, Baltimore: 1063-1065.

Ouwehand, A.C. and Salminen, S.J. (1998): The health effects of viable and non-viable cultured milk. Int. Dairy J. 8: 749-758.

Oliveira, C.A. and Germano, P.M. (1997): Aflatoxin current concept on mechanism of toxicity and their involvement in the etiology of hepato cellular carcinoma. Review Saude Publica, 31, $4: 417$.

Park, D.L. and Pohland, A.E. (1986): A rationale for the control of aflatoxin in animal feeds. In P. S. Steyn \& R. Vleggaar (Eds.), Mycotoxins and phycotoxins: 473-482. Amsterdam: Elsevier Applied Science.

Pelinescu, D.R.; Sasarman, E.; Chifiriuc, M.C.; Stoica, I.; Nohita, A.M.; Avram, I.; Serbancea, F. and Dimov, T. V. (2009): Isolation and identification of some Lactobacillus and Enterococcus strains by a poly phasic taxonomical approach. Romanian Biotechnological Letters, 14: 4225-4233.

Salminen, S.; Ouwehand, A.; Benno, Y. and Lee, Y.K. (1999): Probiotics: How should they be defined? Trends Food Sci. Technol. 10: 107-110.

Sarimehmetoglu, B.; Kuplulu, O. and Celik, T.H. (2003): Detection of aflatoxin $\mathrm{M}_{1}$ in cheese samples by ELISA. Food Control, 15: 45-49.

Schuller, P. and Egmond, H. (1991): Detection and determination of mycotoxins in food and feed. J. Food Protec. 44 (8): 227-231.

Sgouras, D.; Maragkoudakis, P.A.; Petraki, K.; Martinez-Gonzalez, B.; Eriotou, $E$. Michopoulos, S.; Kalantzopoulos, G; Tsakalidou, E. and Mentis, A. (2004): In vitro and in vivo inhibition of Helicobacter pylori by Lactobacillus casei strain Shirota. Applied and Environmental Microbiology, 70: 518-526.

Shan, S.M. (1991): Economic significance of mycotoxins In: Mycotoxine, Cancer and Health (Braz, G.A. and Rzan, D. H. ed.) $1^{\text {st }}$ ed. Louisiana State University Press Baton Rough: 43.

Tamime, A.Y. and O'Connor, T.P. (1995): Kishk: A dried fermented milk / cereal mixture. Int. Dairy J.: 109-128.

Tamime, A.Y.; Barclay, M.N.; Amarowicz, A. and McNulty, D. (1999): Kishk - a dried fermented milk/cereal mixture. 1. Composition of gross components, carbohydrates, organic acids and fatty acids. Lait 79: 317-330. 
Thirumala-Devi, K.; Mayo, M.A.; Hall, A.J.; Craufurd, P.Q.; Wheeler, T.R.; Waliyar, F.; Subrahmanyam, A. and Reddy, D.V. (2002): Development and application of an indirect competitive enzyme-linked immunoassay for aflatoxin $\mathrm{M}(1)$ in milk and milk-based confectionery. Journal of Agricultural and Food Chemistry, 50, 933-937.

U.S. Food and Drug Administration (2011): Guidance for industry: Action levels for poisonous or deleterious substances in human food and animal feed. Available in: http://www.fda.gov/Food/Guidance

ComplianceRegulatoryInformation/Guidance Documents/ChemicalContaminantsandPesticid es/ucm077969.htm Last accessed 21.07.11

WHO and FAO (2001): Health and nutritional properties of probiotics in food including powder milk with live lactic acid bacteria. Report of a joint FAO/WHO expert consultation. Geneva: World Health.

\section{دراسات عن الحالة الصحية لمنتج الكثك \\ لمياء محمدـلعت علي الشريف ، مروة محمد نبيل الجندي \\ Email:moazahmednofel@yahoo.com}

أجريت هذه الدر اسة لتقييم الجودة الصحية للكثك المنتج في قري محافظة أسيوط. استهدفت الدر اسة معرفة مدى احتو اء الكثلك على

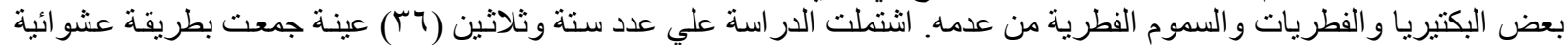

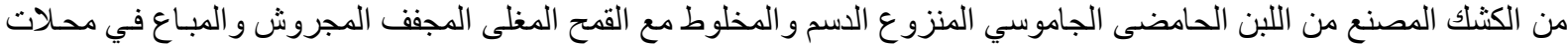

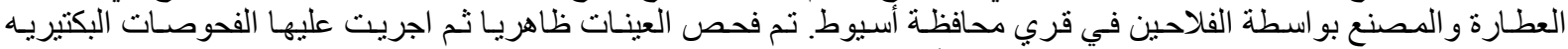

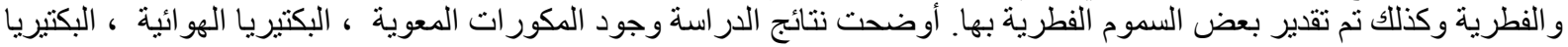

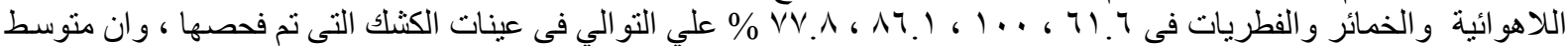

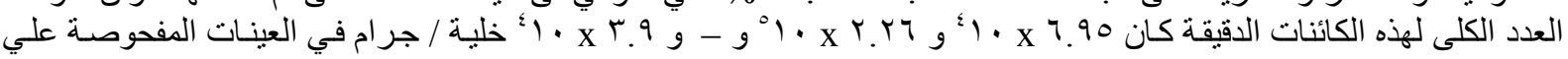

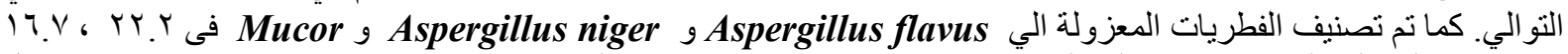

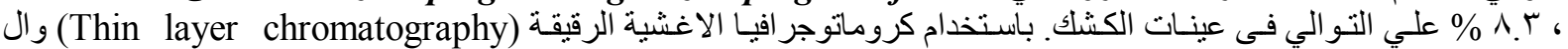

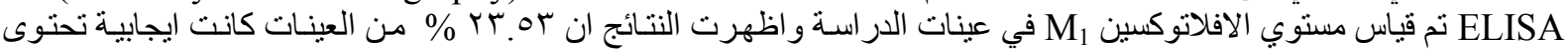

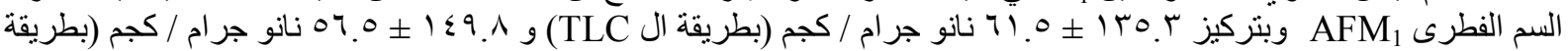

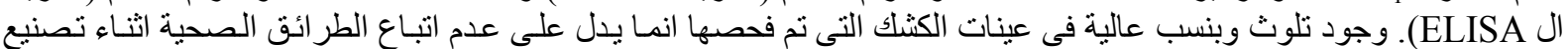

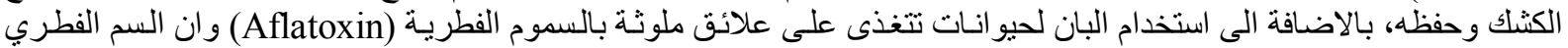
AFM1 المصرية (Egyptian regulations)، لكن نظر الخطورة ال AFM

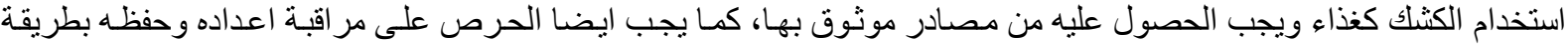

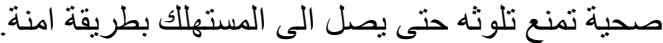

